\title{
Of poverty prevention in the Pentateuch as a continuing contemporary challenge
}

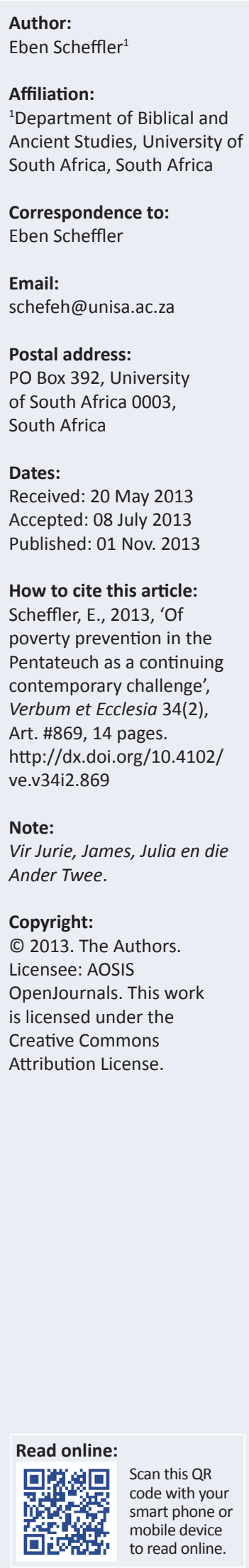

This article surveyed how the theme of poverty and caring for the poor functions in the Pentateuch in its legal as well as narrative sections. It included the discussion of a (hopefully) representative selection of texts where the various Hebrew terms (ani or anw, ebjon and dal) are employed, but also where they are absent but the issue is present. Attention is (amongst others) paid to the goodness of creation as counter-pole for poverty in Genesis 1-3, poverty prevention in the Joseph novella, the Exodus as liberation text, the survival of the Israelites during the desert journey (Dt 8) and the specific measures prescribed in the Covenant Code (Ex 20:22-23:33), the Deuteronomic Code (Dt 12-26) and the Holiness Code (Lv 17-26). It is contended that the various expressions regarding poverty originated and functioned contingently in their ancient contemporary contexts but that they can also be critically appropriated in present-day contemporary contexts - for which a great need exists. The article concluded with ten (preliminary) statements to the latter effect.

'Freedom is meaningless if people cannot put food in their stomachs, if they can have no shelter, if illiteracy and disease continue to dog them.' (Nelson Mandela)

\section{Introduction}

There is a wealth of material that deals with poverty in the first five books of the Bible, although it constitutes by no means the only theme. However, as the Pentateuch-narrative or novel, to a large extent, deals with the promises to a helpless Israel regarding descent and the promised land (Clines 1976, 1995:189-190; Deist 1988:4)1, the theme of poverty becomes (one) window through which everything can be viewed. Because of constraints of space, we can only focus on some areas. To obtain a broad impression, we do not limit ourselves to what became the authoritative Mosaic laws but also look at some narrative material. ${ }^{2}$ We therefore briefly refer to the stories of creation (Gn 1-3), the Joseph novella (Gn 37-50), the Exodus narrative, the desert journey and the traditionally distinguished Covenant Code, Deuteronomic Code and Holiness Code (see also the treatments of Berges 2000; Blomberg 1999:33-50; Lötter 2008:59-72). In a hermeneutical reflection (to be done with trepidation) some remarks will be made about present-day challenges in view of the insights gained from the Pentateuch.

The term 'contemporary' in the title has a double implication, (1) the ancient context(s) in which the biblical text(s) functioned and (2) the present-day context in which an attempt is made to responsibly appropriate these texts and the historical constructions we made regarding them. This implies movements in our mind from the present to the past and back, which happen not only once but on a continued basis. ${ }^{3}$ Even if we pretend to be busy with the past, our present-day concerns are always at work. Likewise, as we consciously attempt to 'appropriate' the text for today (as in our 'hermeneutical reflection' below), we are confronted with the 'past-ness' of the text we are dealing with. ${ }^{4}$

A clarification of what we mean by poverty (and the Hebrew terms used for it), is not only needed for the reflections that follow, but is, in itself, a preliminary example of the to-and-fro interpretative process.

1.Clines (1976, 1995:190) refers to the 'fulfilment and the non-fulfilment of the three-fold promise', whereas Deist (1988:4) claims that 'the Hexateuch deals with God's power to remain faithful to promises which he had made to people who could not help themselves'.

2.Eissfeldt (1964:208), admitting to the awkward abundant presence of narrative and legal material in especially Exodus 19 to Deuteronomy 30 , notes that this was a source of offence to Johann Wolfgang Goethe. However, if one endeavours to empathetically understand the Pentateuch in terms of the life issues that caused this literature to be written, the non-aesthetic character becomes - although by no means diminished - at least understandable. God's actions in the past form the basis for Israel's faith which has an ethical dimension. This (salvation) history could only be narrated and the laws were conspicuously included in this narrative as given by God at certain crossroad(salvation) history could only be narrated and the laws were conspicuously included in this narrative as given by God at certain crossroad-
occurrences (especially the Sinai event). In Matthew's gospel this process is remarkably repeated in the Sermon on the Mount (Mt 5-7).

3.Schröter (2007:1) remarks in this regard: 'Damit sollte herausgestellt warden, dass es stets denkende und handelende Menschen sind, die sich die Vergangenheit aneignen - sie als Geschichte "konstruieren" -, um ihre Gegenwart besser zu verstehen.'

4.During the numerous discussions which I have had the privilege to have with Jurie le Roux, he emphasised these aspects which are responsible for the possibility of 'Horizontsverschmeltung' in the Gadamerian sense. 


\section{What kind of poverty?}

From the outset, the intention of this article is to investigate poverty in terms of its basic meaning, namely economic material destitution, in view of its prevention and eradication. The terms are sometimes metaphorically used (as the wellknown 'the poor in spirit' of Mt 5:3) to indicate 'spiritual

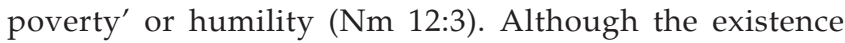
of such notions are not denied, this is not our main concern here. Middle-class Bible readers often refer to the metaphorisation of the term to avoid being confronted with the uncomfortable challenges regarding literal poverty as manifested in the texts - and moreover they appear to be very 'spiritual' or 'religious' in doing so. ${ }^{5}$ It is our expressed aim to close this gap.

\section{Hebrew terms for poverty in the Torah}

In the Hebrew Bible there are especially four terms (ani or anw, ebjon, dal and rasj) that designate poverty, of which the first three occur in the Torah. It is very difficult to distinguish the meanings inherent in these terms and the context(s) in which they appear should be used to determine the exact meaning (cf. Berges 2000:229-234; Groenewald 2003:147-153).

The term ani occurs 80 times in the Tanach (7 times in the Pentateuch $)^{6}$, anaw 24 times ( 1 time in the Pentateuch $)^{7}$ and the substantive oni 36 times ( 9 times in the Pentateuch) ${ }^{8}$. Scholars generally agree that these terms have the same basic root (the verb anah II) and are therefore indistinct in meaning (Clines 2009:334-336; Martin-Achard 1976:341-350). They can be translated as 'poor' and 'humble', the latter referring to a more spiritual meaning. Material poverty is implicated in Leviticus 19:10: 'You shall not gather the fallen grapes of your vineyard; you shall leave them for the poor (ani) and the sojourner.' Humbleness is implicated in Numbers 12:3: 'Now the man Moses was very meek (anw) ...'

The Hebrew term ebjon occurs 61 times in the Old Testament, but only 9 times in the Pentateuch, mostly in Deuteronomy $15 .{ }^{9}$ Originally, it referred to 'beggars' and later it was used to describe the 'socially weak', 'miserable' or 'poor' person.

The term dal can be translated as 'low', 'helpless', 'insignificant' or 'poor' and occurs 48 times in the Hebrew Bible, but only 5 times in the Torah. ${ }^{10}$ In Leviticus 14:21, the offering of the

5.See Schmithals (1980:62), who avoids any reference to the poor in Luke $4: 18$, interpreting Luke's quotation of Isaiah 61:6; 58:6 (including the reference to the Jubilee of Lv 25:10) in terms of 'die Botschaft der Vergebung' ['of the guilt of sins'] thereby 'metaphorising' the economic implications of Leviticus 25, the Isaian tex from which Luke quotes, Luke's own intention, as well as that of the historical Jesus whom Luke attempts to give a hearing. Such an interpretation simply does not hold water, as can be easily illustrated in reference to the Gospel as a whole (see Scheffler 1993:25-48).

6.Exodus 22:24; Leviticus 19:10; 23:22; Deuteronomy 15:11; 24:12, 14, 25 (Lisowsky 1958:1098).

7.Only in Numbers 12:3; cf. also the occurrences in Proverbs 15:15; Ecclesiastes 6:8; Amos 2:7; Psalms 149:4.

8.Genesis 16:11; 29:32; 41:52; Exodus 3:17; Deuteronomy 16:3.

9.Exodus 23:6, 11; Deuteronomy 15:4, 7, 9, 11; 34:14.

10.Genesis 41:19 (of cow); Exodus 23:3; 30:15; Leviticus 14:21; 19:15. 'poor' is referred to: 'If he is poor (dal) and cannot afford much, then he shall take one male lamb for a guilt offering to be waived ...'

The term rash (the participium of the verb rush) occurs 21 times in the Hebrew Bible, but not in the Pentateuch. It usually refers to material poverty, as is clear from the reference to the poor man in the parable of Nathan to David (2 Sm 12:3; see also 2 Sm 13:8; Ecc 4:14; Ps 82:3).

From the above, it becomes clear that of the 270 references employing the classical Hebrew terms for poverty, relatively few $(31,11 \%)^{11}$ occur in the Pentateuch (a third [10] in the book of Deuteronomy and 1 [in metaphorical sense] in Numbers). This may create the impression that poverty is not such a burning issue in these texts. As I hope to indicate below, such a conclusion is far from the truth. Before investigating these texts, some present-day distinctions are called for.

\section{A present-day distinction: Extreme, moderate and relative poverty}

It would facilitate our discussion if we attempt to be more precise, even if our expressed concern is poverty in its material sense. Sachs (2005a:20-24; cf. also 2005b:26-36) (in his important book The end of poverty) makes a distinction between extreme, moderate and relative poverty.

Extreme poverty or absolute poverty refers to 'the poverty that kills', where people have less than \$1 (about R10) per day to survive, are chronically hungry, deprived of basic shelter, safe drinking water, sanitation, sufficient clothing, health care and education. ${ }^{12}$ Moderate poverty is where people live on between $\$ 1$ and $\$ 2$ a day and their needs are barely met. ${ }^{13}$ Lastly, relative poverty is based on a household income below a given proportion of the national average. People in relative poverty lack things that the middle class takes for granted. ${ }^{14}$ In view of the extremity of the first two categories, this category will not be our main concern in exploring the concept in the Torah. With these distinctions in mind we now turn to selected texts of the Pentateuch.

11.The Torah constitutes about $25 \%$ of the Tanach. This means that in comparison with the Hebrew Bible as a whole, based only on the statistical information, the latter contains twice as much material on poverty. For comparison, it can be mentioned that there are about 150 references to poverty in the book of Proverbs alone $(50 \%$ of the occurrences in the Tanach, whilst constituting about only $2 \%$ of the latter). Ir the oculter) seems to be the less positively inclined to the poor (see Scheffler 2012:480-496).

12.About 1 billion of the world's population (one-seventh) falls into this category. More than 8 million people die every year (between 20000 and 30000 a day!) as a result of extreme poverty, mainly in the developing countries. Asia leads in as a result of extreme poverty, mainly in the developing countries. Asia leads in half its population (approximately 300 million). What makes Africa's situation also qualitatively worse is the fact that, in terms of the population proportion, the situation is worsening in Africa, whereas in Asia the situation is improving. The situation of the extreme poor is further worsened by factors such as HIV and AIDS, drought, isolation and civil wars. What proportions existed in ancient Israel at various stages of its history is difficult to determine, but that such poverty existed is clear from the archaeological record (cf. Scheepers 2012:23-41) and passages such as Job 24 and 29:12-17, where the oppression of and Job's care for the extreme poor is vividly described. Compare also Psalms 109:6-20, where such poverty is wished for the enemy (see Scheffler 2011a:192-207).

13.Another 1 billion people fall within this category.

14.This category makes for a further 1 billion people, which implies that if relative poverty is indeed to be regarded as poverty, then almost half of the world's population is poor. 


\section{Remarks on Genesis 1-3: Poverty, despite the good creation}

As is clear from the archaeological record, poverty seems to have been with Israel from the beginning of its existence. The early Israelites had to struggle to survive (Scheepers 2012). In their cultural memory as reflected in the biblical tradition, this 'struggle for survival' was according to the Israelites part of humanity's fate from the beginning of its existence. The creation stories of Genesis 1 and 2 picture a time (in the mythic past) when God created the world and paradise and when there was enough for everyone to eat. Soon, the situation changed and wealth or sustainability was not an automatic given anymore. In Genesis 3, Yahweh Elohim said to Adam:

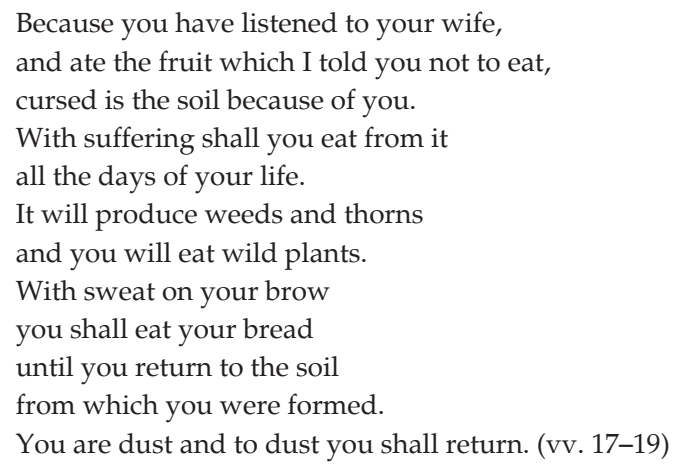

From the perspective of the problem of poverty, the story of the Fall can be read as an etiological story, which originated later in Israel's history, to explain (amongst other things) an important aspect of the condition humanitas: the fact that human beings have to work hard in order to overcome poverty.

Having 'explained' poverty in this way, the narrative of a perfect creation (Gn 1), on the other hand, clearly communicates that God did not intend human beings to be poor. Although poverty is interpreted as a kind of punishment, Genesis 1 states clearly that God intended the creation to be good (see especially the expression 'and it was good' after the plants that produced food had been created [Gn 1:13]).

Another point should also be mentioned. Many people construe religion as a spiritual matter, whereas the matters of everyday life are regarded as being 'material(istic)' and belonging to the sphere of our earthly existence. According to Genesis 1, quite the opposite is true. Creation does not begin with the beginning of the universe (which had been there) but with this very earth on which humans live. Although human beings will struggle to survive, their punishment is not total extinction but the fact of their struggle, which is in a sense therefore also affirmed. The biblical account of Israel's history, which the Bible reflects, is therefore also the story (with its successes and failures) of how Israel took up this challenge.

\section{Poverty prevention in the Joseph Novella}

The Joseph story is well known and appears in Genesis 37-50 (chapter 38 excluded). It narrates the story how Joseph was sold by his brothers (because of his arrogance) and ended up in the Egyptian court. When a famine (extreme poverty) broke out in Israel, Jacob sent his sons to buy food in Egypt, where they were all ultimately reconciled with Joseph. What interests us here in the context of poverty eradication are the basic economic principles that the story (besides other themes) reflects.

The Joseph story has now long been regarded as a wisdom story, because the message of the story communicates principles of wisdom which we also found (amongst other things) in the book of Proverbs (see Loader [n.d.]; Scheffler 2012; Spangenberg 2012; Von Rad 1974:22-41). Joseph was arrogant before his brothers and then he was humiliated by being thrown in a pit. His brothers humiliated him and they were humiliated in the end before Joseph. This motif correlates with the wisdom motif, which states that God will humiliate arrogant people (Pr 16:5, 18).

As far as human subsistence is concerned, a wisdom book such as Proverbs also abounds in adages that praise those who observe diligence and work hard, whereas those who merely sit back and enjoy the times of prosperity will have nothing to eat in times of need (e.g. Pr 6:9-11[=24:33-34]; $10: 4 ; 12: 11 ; 20: 4 ; 21: 17 ; 28: 19)$.

The Joseph story vividly narrates how Jacob and his sons experienced a famine and had to go to Egypt for help. The 'wisdom', which in the Joseph story is expressed in the motif of the seven lean years and the seven fat years, is most probably directed at bad economic principles that were practiced at a certain stage (or stages) in Israel's history. It communicates an economic theory of economic upswings and downswings that come in cycles. As such, this insight sounds extremely modern, for we all know the phenomenon. It examines Israel's (and anybody's) foolishness at having consumed everything during periods of prosperity, without saving for times of need. It thus communicates that poverty can to a great extent be prevented if humans would but keep this 'wise' principle in mind. Interestingly enough, many individuals and governments fail to observe this principle. That it can be done can be learnt from the Egyptian's ${ }^{15}$ (and Joseph's; although, ironically not Israel's!) behaviour in the Joseph novella.

\section{The Exodus narrative as a liberation text}

There is a certain irony that (according to the biblical narrative) the Israelites went to Egypt to get rid of their poverty, but in the end were enslaved. This is also a lesson to be learnt from history: circumstances never stay the same and human beings must never become complacent within the comfort zone in which they find themselves. For another Pharaoh may come, 'who did not know Joseph' (Ex 1:8). The slavery (and the poverty implied by it) inflicted on the Israelites was cruel:

15.The existence of economic injustice in Egypt is not hereby denied, as peasants in Egypt and their lands were bought for the Pharaoh. 
So the Egyptians put slave-drivers over them to crush their spirits with hard labour.

... But the more the Egyptians oppressed the Israelites the more they increased in number ... They made their lives miserable by forcing them into cruel slavery.

They made them work on their building projects and in their fields,

and they had no mercy on them. (Ex 1:11)

The narrative clearly communicates that God was not pleased with his people being treated like this. He appeared to Moses and told him:

I have heard them cry out to be rescued from the slave-drivers. I know all about their sufferings, and so I have come down to rescue them from the Egyptians and to bring them out of Egypt to a spacious land, one which is rich and fertile ... (Ex 3:7-8)

It has been a well-established fact throughout history that religion is often used by oppressive governments and powers to justify their actions of oppression of peoples and individuals. On the Merneptah stele (dating from late 13th century BCE), Pharaoh Merneptah celebrated his victory over the Canaanite peoples. That it was done in the name of religion is clear from the relief at the top of the stele where Amon-Re, the god of Karnak, presents a victory sickle and royal sceptre to Merneptah. Of the Canaanite peoples (amongst others Israel), it is said on the stele that:

Canaan is plundered with every evil

Ashkelon is taken, Gezer is captured

Yanoam is made non-existent

Israel lies desolate, its seed is no more ... (cf. see Scheffler

2000:82-85 for a detailed discussion of the Memeptah stele)

Here, 'lies desolate' implies extreme poverty; 'its seed is no more' implies no offspring. This is poverty taken to its ultimate conclusion: death and extinction. And religion is used to justify it.

The Exodus narrative (as do many other biblical texts) militates against such a use of religion. It depicts a God who has empathy for the sufferings of human beings and who (by means of human leaders such as Moses) liberates people from oppression. Throughout their history (e.g. the exile), the Israelites drew inspiration from the Exodus tradition: in fact, one can say that it became the founding tradition of the nation (see amongst others Ex 20:2; Nm 23:22-24; Jdg $6: 13 ; 1 \mathrm{Sm} \mathrm{4:8;} 2 \mathrm{Sm}$ 7:23; Ps 136:10-15). As such, the Exodus tradition also inspired many oppressed nations throughout history. It inspired the establishment of a Jewish state in 1948, as well as liberation theology in Latin America, the USA and (southern) Africa.

Despite the central role of the Exodus tradition in the history of Israel, it should be noted that not all Israelites always lived according to its tenets. The otherwise famous and acclaimed King Solomon also (like the Pharaoh) used forced labour (especially from northern Israel) for his building projects (1 Ki 5:13-16). The text explicitly states that 'at Solomon's command they quarried fine large stones for the foundation of the Temple'. Again, the role of religion is noteworthy: people were exploited to build a temple. The case of King Ahab is also well known. He took Naboth's vineyard to enrich himself (see extensive discussion by Farisani 2012). Whereas the narrative of 1 Kings 21 criticises Ahab's behaviour, the law of Deuteronomy (written long after Solomon) warns against Solomon's behaviour:

[The king] is not to make himself rich with silver and gold ...

He is to read from this book [the law] ...

This will keep him from thinking he is better than his fellowIsraelites ... (Dt 17:17, 19)

According to the Exodus narrative, God sided with the Israelites when they were oppressed. However, this fact did not safeguard them from oppressing and exploiting the poor themselves. Laws were therefore needed in Israelite society to protect the poor from exploitation and to enhance the alleviation of the poor's suffering. Before having a closer look at some of these laws, another instance of poverty in the Exodus narrative (and its interpretation) demands our attention.

\section{Testing by poverty during the desert journey}

Exodus 16 and Numbers 11:4-33 narrates how the Israelites were materially deprived during the desert journey after their liberation from Egypt on their way to the promised milk and honey of Canaan. They were materially deprived to such an extent that they were prepared to lose their political freedom if they only could have the adequate food they enjoyed in Egypt (Nm 11:5). The text conveys an important truth, namely that poverty eradication has a priority over political liberation (which means nothing if stomachs are not fed). The story narrates how, despite their disobedience, God provided in their needs by means of manna and quails.

Deuteronomy 8 reflects on these events and interprets them as a testing of and a lesson to the Israelites:

Remember the long way that the Yahweh your God has led you these forty years in the wilderness, in order to humble you, testing you to know what was in your heart, whether or not you would keep his commandments. (3) He humbled you by letting you feel hunger, then by feeding you with manna, with which neither you nor your ancestors were acquainted, in order to make you understand that one does not live by bread alone, but by every word that comes from the mouth of the Yahweh. (vv. 2-3)

In Canaan, the Israelites will experience wealth and abundance, ${ }^{16}$ but they should remember the desert experience and the liberation from slavery in Egypt (Dt 8:13-14) as being at the basis of their existence. Moreover, these events should motivate them to keep the Mosaic Law.

It is interesting to note, contrary to the default position in the Israelite tradition which usually values poverty as something negative to be avoided, that in this case it is used by Yahweh

16.Deuteronomy 8:7-10 paints a picture of the luxurious life in Canaan: '... a land with flowing streams, with springs and underground waters welling up in valleys and hills, a land of wheat and barley, of vines and fig trees and pomegranates, a land of olive trees and honey, a land where you may eat bread without scarcity, where you will lack nothing, a land whose stones are iron and from whose hills you may mine copper. You shall eat your fill and bless Yahweh your God for the good land that he has given you'. In view of the archaeological record and what we know about subsequent history, this portrait can hardly be reconciled with reality. The function most probably is to warn against apostasy from Yahweh and his commandments amongst the more wealthy sections of the society. 
to 'educate' the Israelites and to motivate them to keep the law which - ironically - would contain measures to eradicate poverty in the community. ${ }^{17}$ To some of these we now turn.

\section{Caring for the poor in Mosaic Law The Covenant Code}

Exodus 20:22-23:33, which follows directly after the Ten Commandments, contains several laws meant to regulate ancient Israelite society, who were perceived to live in a covenant with Yahweh. This collection of laws (also believed to be given to the Israelites at Mount Sinai) is relatively old (it probably originated in the 8th or 9th centuries BCE) and is known in scholarship as the Covenant Code (cf. Otto 1994:24; Zenger 1998:173-175).

In the Code, several practical prescriptions are made that benefit the poor. ${ }^{18}$ These prescriptions are reckoned to the older pre-priestly sections of the Torah and may probably date back to the 9th or 10th century BCE (Zenger 1998:162-180). The context is clearly not urban, but that of peasants of the land fighting for their basic existence (the extended cultural community). The liberation experienced in the Exodus forms the angle from which poverty should be judged.

Firstly, there is a limit set to the suffering of people who were forced to sell themselves as slaves: they should be released in the sabbatical year (Ex 21:2) and a slave-girl becoming part of a polygamous relationship should be treated fairly (Ex 21:10-11):

When you buy a male Hebrew slave, he shall serve six years, but in the seventh he shall go out a free person, without debt. (Ex 21:2)

If he takes another wife to himself, he shall not diminish the food, clothing, or marital rights of the first wife. And if he does not do these three things for her, she shall go out without debt, without payment of money. (Ex 21:10-11)

These measures were intended only for Hebrew (not foreign) slaves. Although slavery is not completely abolished (as we would wish from a present-day perspective), the measures are nevertheless meant to curtail absolute exploitation.

Secondly, foreigners, widows and orphans (in a patriarchal society the latter were especially exposed to extreme poverty) should not be ill-treated (Ex 22:21-24) or God's wrath would be invoked:

You shall not wrong or oppress a resident alien,

for you were aliens in the land of Egypt.

17.The allowance for the 'ascetism' of the Nazirenes ( $(\mathrm{Nm} 6: 1-21)$ is another instance where poverty (but only in the sense of sobriety) seems to have a positive function. Nazirenes chose such a lifestyle, which was not the rule of thumb for the ordinary Israelite.

18. The theme of poverty does not dominate the Covenant Code, but is embedded in it. The Code furthermore deals with prescriptions regarding sacrifice on the altar(s) (Ex 20:22-26), slaves (Ex 21:1-11), homicide and assault (Ex 21:12-36), compensation for thefts and other offences (Ex 21:37-22:14), violation of a virgin (Ex 22:15-16), against sorcery, bestiality and idolatry (Ex 22:17-19), treatment of the poor (Ex 22:20-27), first-fruits and the first-born (Ex 22:28-31), even-handed justice to the enemy and the poor (Ex 23:1-9), the sabbatical year and the poor (Ex 23:10) the Sabbath (Ex 23:12-13), the feasts of the Unleavened Bread, the Harvest and the Ingathering (Ex 22:24) and includes an epilogue relating to promises and instruction (Ex 23:20-33).
You shall not abuse any widow or orphan.

If you do abuse them, when they cry out to me,

I will surely heed their cry;

my wrath will burn, and I will kill you with the sword,

and your wives shall become widows and your children orphans.

(Ex 22:21-24)

Thirdly, if money is lent to anyone of the poor (ani - Ex 22:25) who is a compatriot, no interest should be charged:

If you lend money to my people, to the poor among you, you shall not deal with them as a creditor;

you shall not exact interest from them. (Ex 22:25)

No interest implies that the act of lending is actually an act of giving, because even no interest should be charged to compensate for inflation. ${ }^{19}$ Cancelling of the debts (as in Dt 15, see below) increases the act of giving even more.

Fourthly, the protection of the weak is a special characteristic of the Mosaic Law. Noteworthy is the ruling when extreme poverty in terms of physical survival is concerned: the cloak that may be taken as a pledge for borrowed money should be returned before sunset because it is the only covering that can keep the poor person warm (Ex 22:25-27). A very 'humane' measure indeed, based on the compassion of Yahweh, and manifested in an apparently insignificant way:

If you take your neighbor's cloak in pawn,

you shall restore it before the sun goes down;

for it may be your neighbor's only clothing to use as cover;

in what else shall that person sleep?

And if your neighbor cries out to me,

I will listen, for I am compassionate. (Ex 22:25-27)

Fifthly, justice to the poor (dal), a recurring motif in the psalms, is also considered in the Covenant Code: it should be even-handed, no partiality should be shown to the poor and neither should justice be denied them (Ex 23:2-3, 6):

... you shall not side with the majority so as to pervert justice; nor shall you be partial to the poor in a lawsuit.

You shall not pervert the justice due to your poor in their lawsuits. (Ex 23:2-3, 6)

Sixthly, the Sabbath year, which has the ecological function of sparing the land (cf. also the version in the Holiness Code below), also benefits the poor (ebjon) who could eat whatever grows there:

For six years you shall sow your land and gather in its yield; but the seventh year you shall let it rest and lie fallow,

so that the poor of your people may eat;

and what they leave the wild animals may eat.

You shall do the same with your vineyard, and with your olive orchard. (Ex 23:10-11)

Lastly, interesting also is the version of the commandment to keep the Sabbath, which is formulated from the perspective of the toil and moil of the animals, slaves and strangers, whereas in Exodus 20:8-11 it is based on God's rest on the seventh day of the first creation narrative:

Six days you shall do your work, but on the seventh day you shall rest,

19.The Israelites of course did not know the term, but it cannot be ruled out that they would have experience the concept of devaluation of money. 
so that your ox and your donkey may have relief,

and your home-born slave and the resident alien may be refreshed. (Ex 20:8-11) $)^{20}$

Closely considering these measures, one can conclude that they are all embedded in and related the context into which they originated. As such they would be re-interpreted and reapplied in the later Codes (see below). One can almost say that they are an antique example of situation ethics, governed by the over-arching principle of love and justice that cares for the poor. ${ }^{21}$

\section{The Deuteronomic Code}

The classical view of De Wette (1869; see also Otto 2000:3) links Deuteronomy to the reform movement that took place during the reign of Josiah (639-609 BCE), as reported in 2 Kings 22-23. These reforms had the centralisation of the cult in Jerusalem as its main purpose, but it stands to reason that other issues (as mentioned in Deuteronomy) were also covered (e.g. idol worship and poverty).

Presently, in what can be described as a major paradigm shift in Pentateuchal studies (which involves the abandonment or at least radical adaptation of the four documentary hypothesis), the book of Deuteronomy becomes the linchpin in the development of the Pentateuch. The context is the 7th century BCE and the reign of Josiah, but the beginnings of Deuteronomy (especially chapter 13) are seen as a reaction against the vassal treaties of King Essarhaddon of Assyria, who demanded total loyalty from his subjects. Deuteronomy took over some of these texts but demanded complete loyalty to Yahweh (instead of, or in direct opposition to, Essarhaddon). The possible northern origin of the Code is thereby underplayed. This view is advocated by Otto (1994:180-186, 2000) and propagated by Le Roux (2005:15-18).

The Deuteronomic Code (Dt 12-26, especially 15:1-18), contains prescriptions which could probably date back to the 7th century and covers (amongst others) economic problems brought about by a primitive capitalist monetary economy which started to develop. A money system was in full swing and contact through trade existed between Judah and the rest of the Near East. Judah was, at this stage, under Assyrian hegemony and tributes that had to be paid to the Assyrian king threatened the cohesion of society. In this context, where money could be borrowed to compensate for economic losses, poverty became a burning problem. Judean intellectuals (who were responsible for the text) experienced an unsatisfactory reality and visualised a better one. Deuteronomy 15 especially examines this (for the author[s]) untenable situation and attempts to make suggestions for the regulation of money matters amongst members of the Judean people.

20.The Sabbath command according to the Covenant Code has a remarkable resemblance with the humanistic perspective of the Marcan (and most probably historical) Jesus: 'The sabbath was made for humankind, and not humankind for the sabbath; so the Son of Man is lord even of the sabbath' (Mk 2:27-28; cf. Mt 12:8; Lk 6:15).

21.Fletcher (1966:36) formulates: '... situation ethics holds flatly that there is only one principle, love, without prefabricated recipes for what it means in practice, and all other so-called principles or maxims are relative to particular, concrete situations'.

\section{Caring for the poor in Deuteronomy 15:1-18}

Deuteronomy 15:1-18 contains the classic text dealing with poverty eradication and poverty prevention, not only in Deuteronomy but even in the Pentateuch as a whole. Having discussed it extensively in a previous contribution (Scheffler 2005, 2008; see also Berges 2000; Oosthuizen 1997; Otto 1994), the remarks here will be limited.

The text consists of four subsections (measures for the remission of debts, rewards for obedience in doing so, measures to care for the poor, and measures for generosity towards slaves) which will be discussed in succession (biblical verses in brackets).

\section{Three measures for the remission of debts (Dt 15:1-3):}

- At the end of every seven years you must cancel debts. (2a) This is how it should be done:

- (2b) Every creditor shall cancel the loan he has made to his fellow Israelite.

(2c) He shall not require payment from his fellow Israelite or brother (ach), because the Lord's time for cancelling debts has been proclaimed.

- You may require payment from a foreigner (nokri), but you must cancel any debt your brother owes you. (Emphasis added)

The poor (ebjon) are actually debtors who have to face creditors. The shemitta (the law of 'release'; see Dt 15:1) of the Sabbath year is accordingly a reinterpretation of the Covenant Code's demand for a Sabbath year of rest for the land (cf. Ex 23:11) in the new context. In the legislation envisioned in Deuteronomy 15:1-11, the solidarity as expressed by family life (the term ach [brother] is often used) forms the motivation for the eradication of poverty.

There is a nationalistic attitude in the text that cannot be denied. The demand to alleviate poverty is not a demand to be exercised on a universal scale, but within the boundaries of one's own community. In the text this is clear when a distinction is made between the ach (brother) and nokri (foreigner, not the ger or stranger living in the midst, cf. Ex 22:21-24 and Dt 24:21-24). The line of reasoning could have been that the shemittah rule applies only to those who pay tax in the country and because foreigners residing outside the country (nokrim) do not, they are excluded. The text, however, also reveals a possible urge to lend to other peoples and to rule over them. This can be interpreted either positively (Israel as blessing for the nations) or negatively (an imperialistic urge).22

\section{Four rewards for obedience for caring for the poor (Dt 15:4-6):}

- (4a) There should be no poor among you

- (4b) for the Lord will richly bless you in the land which the Lord your God is giving you to possess as your inheritance. (5) The condition is that you fully obey the Lord your God and are careful to follow all these commands I am giving you today.

- (6a) For the Lord your God will bless you as he has promised: (6b) you will lend to many nations but will borrow from none.

22. Within our present-day context this has significance, because the ethic implied by the negative interpretation has similarities with the exclusive ethic that prevailed under National Socialism in Germany and apartheid in South Africa (charity is to under National Socialism in Germany and apartheid in South Africa (charity is to
be practiced only to the benefit of the members of one's own group, but to be justified as benefiting the whole world). 
- (6c) You will rule over many nations but none will rule over you. (Emphasis added)

The text expresses a vision of an ideal community, not necessarily a realised one. To what success the measures were successful or exerted an influence in society is hard to determine. It could have differed from locality to locality and from individual to individual. In any case it did not produce a welfare state (cf. fn. 23). God's blessing in terms of the land is promised when his prescriptions are followed. A community without poverty is set as the ideal and the text that was later quoted in Mark's Gospel ('the poor will always be among you', Mk 14:7, see below) serves as a motivation to be generous to the poor.

\section{Five measures to care for the poor (Dt 15:7-11):}

- (7a) If there is a poor man among your brothers in any of the towns of the land that the Lord your God is giving you,

(7b) do not be hardhearted or tightfisted toward your poor brother.

- (8) Rather be openhanded and freely lend him whatever he needs.

- (9a) Be careful not to harbour this wicked thought:

(9b) 'The seventh year, the year for cancelling debts, is near', so that you do not show ill will toward your needy brother and give him nothing.

(9c) He may then appeal to Yahweh against you and you will be found guilty of sin.

- (10) Give generously to him and do so without a grudging heart; then because of this the Lord your God will bless you in all what you do.

- (11) There will always be poor people in the land. Therefore I command you to be openhanded toward your brothers and toward the poor and needy in your land. (Emphasis added)

Noteworthy in these measures is the emphasis on the positive psychological attitude of the benefactors (not hardhearted, open-handed, not begrudging). Mere legal measures are not envisioned to work without the compassion of those who are supposed to care.

Not only does the text express the wish that there should be no poor people (Dt 15:4a) within Judean society (which implies that at the time of writing there were), but it also explicitly states that 'there will always be poor ones amongst you' (Dt 15:11). This statement can be interpreted as a later addition when it became clear that the ideal stated earlier was not realised. It therefore leaves the reader with the overall impression that there should be an attempt to eradicate poverty, but that ultimately it may not be successful. The endeavour should therefore be embarked upon in principle and all vehemence, irrespective of the possibility of success.

\section{Six measures for generosity to slaves (Dt 12:12-18):}

- (12) If a fellow Hebrew, a man or a woman, is sold to you and serves you six years, in the seventh year you must let him go free.

- (13) And when you release him, do not send him away empty-handed.

- (14) Supply him liberally from your flock, your threshing floor and your winepress. Give to him as Yahweh your God has blessed you.
- (15) Remember that you were slaves in Egypt and the Lord your God redeemed you.

That is why I give you this command today.

- (16) But if your servant says to you, 'I do not want to leave you', because he loves you and your family and is well off with you,

(17) then take an awl and push it through his ear lobe into the door, and he will become your servant for life.

Do the same for your maidservant.

- (18) Do not consider it hardship to set your servant free, because his service to you these six years has been worth twice as much as that of a hired man.

Yahweh your God will bless you in everything you do. (Emphasis added)

The slave laws of the Deuteronomic Code interpret those of the Covenant Code. They are more humane than those of Exodus 21:1-11. From our vantage point today we would probably have liked the text to condemn slavery outright and demand its abolition. It is therefore necessary to realise that we cannot impose our own 21st century convictions on the text. However, this does not prevent us from discerning that in the text certain alterations are made to the slave laws that make them even more 'humane', if compared to that of the Covenant Code (Ex 21:1-11). Firstly, the Hebrew slave should not only be released in the Sabbath year without debt, but be supplied liberally with flock, grain and wine. Secondly, in the Deuteronomic Code, the humane measures are extended to all female slaves (Dt 15:12), which makes the rights of female slaves staying behind (Ex 21:7-10) redundant. Thirdly, the maidservant also has the right to stay with the master. Fourthly, an appeal is again made to the positive psychological attitude of the master: he should not begrudge the releasing of the slave. This development towards more 'humaneness' thereby, in itself, actually contains the ethic which, if consequently applied, would imply the abolition of slavery amongst compatriots (as was indeed demanded in the Holiness Code, cf. Lv 25:39-43, see below).

\section{The feasts as an opportunity to care for the poor (Dt 16:1-16)}

In Deuteronomy 16, the celebration of the Passover, the feast of weeks and the feast of tabernacles serve to alleviate the plight of the poor. The usual terms for poverty does not feature, except the term oni (= affliction, poverty) to refer to the bread of the Passover (unleavened) which was eaten in haste (Dt 16:3). The Passover served as a constant reminder of the liberation from slavery which occurred with the Exodus and which motivated the Israelites to care for the afflicted (cf. Dt 16:12).

With the feast of the weeks, the care for the poor became concrete: not only the believer should rejoice in the feast, but also the underprivileged living with him:

Rejoice before Yahweh your God - you and your sons and your daughters, your male and female slaves, the Levites resident in your towns, as well as the strangers, the orphans, and the widows who are among you. (Dt 16:11)

The same applies for the feast of tabernacles. Everyone is also urged to make a contribution to these feasts in accordance with his ability (Dt 16:17) thereby contributing to the care of 
the poor. By mentioning the slaves, strangers, orphans and widows specifically, there is no possibility that the concept 'poor' can be spiritualised.

\section{Further Deuteronomic reinterpretations regarding the poor (Dt 24:6-22)}

In Deuteronomy 24:6-22, more measures of the Covenant Code are repeated, but in a version that befits the Deuteronomic view. The prohibition not to take a mill or millstone as a pledge is unique to Deuteronomy. The text aptly notes that 'that would be to take a life in pledge' (Dt 24:6). Having a mill and millstone was essential for producing daily bread.

Deuteronomy 24:10-13, dealing with the cloak as pledge, repeats the ruling (that the pledge should be returned before sunset) of the Covenant Code (cf. Ex 22:25 above) and adds that the house of the borrower should not disrespectfully be entered to seize the pledge (24:10).

Deuteronomy 24:14-16 is probably a rendering of Exodus 22:21-24, where the strangers, widows and orphans are first mentioned. In the Deuteronomic version, the emphasis is on the hired servant (compatriot or stranger) 'who is poor and destitute' (ani webjon). Wages should be daily paid for the poor person 'is anxious for it' (= puts his heart upon it). The reasoning is clearly from the perspective of the poor persons feelings, who need the money the very same day to survive.

The demand for even-handed justice for the rich (Ex 23:2-3) and the poor (Ex 23:6) is probably rendered in Deuteronomy 24:17, focusing on the stranger, widow (whose garment may not be taken as a pledge) and orphan. The emphasis is here on these well-known categories of poor people and the measure is once again motivated by reference to the Israelite's slavery in Egypt and their liberation by Yahweh their God (Dt 24:17).

It is uncertain whether the measure not to go back and fully harvest the field, olives and vineyard for the benefit of the poor (Dt 24:19-21) get its lead from the benefit of the poor during the lying fellow of the land during the Sabbath year (Ex 23:10-11). The Deuteronomic measure which, in a shorter version, will be repeated in the Holiness Code (see below on Lv 19:10) again focuses on the stranger, widow and orphan, which are here repeatedly (thrice) mentioned, almost in a poetic fashion:

When you reap your harvest in your field and forget a sheaf in the field,

you shall not go back to get it;

it shall be left for the alien, the orphan, and the widow,

so that Yahweh your God may bless you in all your undertakings.

When you beat your olive trees,

do not strip what is left;

it shall be for the alien, the orphan, and the widow.

When you gather the grapes of your vineyard,

do not glean what is left;

it shall be for the alien, the orphan, and the widow.

Remember that you were a slave in the land of Egypt;

therefore I am commanding you to do this. (Dt 24:19-22

[Emphasis added])
Not only does the reminder of the Egyptian experience serve to motivate the concern to care for the poor, the rhetoric of the text enhances it.

\section{The Holiness Code}

In the Holiness Code of Leviticus 17-26, the sanctity of Yahweh forms the vantage point from which the problem of poverty is considered in the post-exilic community by the priestly writer (see Lv 19:1: 'be holy because I, Yahweh your God, am holy'). Some of the measures are similar to those of the Covenant Code. At least four practical prescriptions to the benefit of the poor follow in chapters 19 and 25. Firstly, a conscious effort should be made to leave something to eat for the poor and foreigners in the cornfields and vineyards:

When you harvest your fields, do not cut the corn at the edges of the fields, and do not go back to cut the ear of the corn that were left. Do not go back the grape that have fallen; leave them for poor people and foreigners. I am Yahweh your God. (Lv 19:10)

On this, two remarks can be made: the text is repeated in Leviticus 23:22, which illustrates its importance and one should not imagine the owners of the field or the vineyard are necessarily 'rich people'. Of course, the owners could have been rich, but the impression which the text creates is that 'middle class' people are spoken of: peasants who owned a piece of land (like Naboth in $1 \mathrm{Ki} 21$ ) who could sustain themselves. These people are also especially called upon to be unselfish. As relatively poor people, they should leave something for the extremely poor, those who have nothing.

Secondly, caring for the poor obtains an ecological dimension. Leviticus 25:3-7 provides a reinterpretation of Exodus 23:11 and the shift in emphasis can be clearly seen from the synoptic comparison in Table 1. The Leviticus version does not explicitly mention the poor, but focus of the survival of the household which includes slaves and servants, which implies the poor. The text is explicitly gender inclusive. Contrary to Deuteronomy 15, the text reverts back to the Covenant Code and interprets the shemitta in terms of its original intention, namely the rest of the land which is also emphasised by being designated as a complete rest. It is further emphasised by being mentioned twice (contrary to Ex 23:11). Domestic as well as wild animals are included.

TABLE 1: The ecological dimension of Leviticus 25:3-7 compared with Exodus 23:11.

\begin{tabular}{|c|c|}
\hline Leviticus 25:3-7 & Exodus 23:11 \\
\hline $\begin{array}{l}\text { (3) Six years you shall sow your field, } \\
\text { and six years you shall prune your vineyard, } \\
\text { and gather in their yield; }\end{array}$ & $\begin{array}{l}\text { For six years you shall sow your land } \\
\text { and gather in its yield; }\end{array}$ \\
\hline $\begin{array}{l}\text { (4) but in the seventh year there shall be } \\
\text { a sabbath of complete rest for the land, } \\
\text { a sabbath for Yahweh: } \\
\text { you shall not sow your field } \\
\text { or prune your vineyard. }\end{array}$ & $\begin{array}{l}\text { (11) but the seventh year you shall } \\
\text { let it rest and lie fallow, }\end{array}$ \\
\hline $\begin{array}{l}\text { (5) You shall not reap the aftergrowth of your } \\
\text { harvest } \\
\text { or gather the grapes of your unpruned vine: } \\
\text { it shall be a year of complete rest for the land. } \\
\text { You may eat what the land yields during its } \\
\text { sabbath - }\end{array}$ & $\begin{array}{l}\text { so that the poor of your people } \\
\text { may eat; }\end{array}$ \\
\hline $\begin{array}{l}\text { you, your male and female slaves, } \\
\text { your hired and your bound laborers who live } \\
\text { with you; } \\
\text { for your livestock also, } \\
\text { and for the wild animals in your land } \\
\text { all its yield shall be for food. }\end{array}$ & $\begin{array}{l}\text { and what they leave the wild } \\
\text { animals may eat. } \\
\text { You shall do the same with your } \\
\text { vineyard, } \\
\text { and with your olive orchard } \\
\text { (cf. Lv 25:4) }\end{array}$ \\
\hline
\end{tabular}


The perspective on poverty prevention is embedded into a wide ecological perspective (for a comprehensive discussion of Lv 7:1-7, see Scheffler 2009).

Thirdly, wages should be paid immediately:

Do not take advantage of anyone or rob him.

Do not hold back the wages of someone you have hired, not even for one night. (Lv 19:13)

The reason for immediate payment is probably because a really poor person had no food reserves. The wages for one day was barely enough for a day's food.

Fourthly, justice for the poor did not mean injustice to the rich (Lv 19:15). The measures which are separately transmitted in the Covenant Code (Ex 23:2-3, 6) are not elaborated upon as in the case of the Sabbath (cf. above) but summarised:

Be honest and just when you make decisions in legal cases.

Do not show favouritism to the poor or fear the rich. (Lv 19:15)

Summarising the measures in the Covenant Code, justice to the poor ( $\mathrm{dal}$ ) and the rich ( $\mathrm{gadol}$ ) should be available on an even-handed basis. It is significant that care for the poor does not imply that the justice towards the rich is violated. This may be because the care for the poor is based on justice which is in principle even-handed. It is also logical that the readers of the texts are most probably the upper class whose sympathy for the poor the text wants to invoke. Violating the latter's rights would naturally be counterproductive.

Fifthly the jubilee year, with its measures in Leviticus 25:8-55, is intended to ameliorate the life of the poor who, after 50 years, can get their property back. No cheating should occur in business matters, no interest should be charged or food sold for profit and (contrary to the previous Codes) slavery should not be allowed amongst compatriots. Only selected passages are quoted here and phrases reflecting caring for the poor are written in italics:

(10) And you shall hallow the fiftieth year and you shall proclaim liberty throughout the land to all its inhabitants. It shall be a jubilee for you: you shall return, every one of you, to your property and every one of you to your family. (Lv 25:10)

(14) When you make a sale to your neighbor or buy from your neighbor, you shall not cheat one another. ( $\operatorname{lv} 25: 14$ )

(25) If anyone of your kin falls into poverty and sells a piece of property, then the next of kin shall come and redeem what the relative has sold. (Lv 25:25)

(28) But if there is not sufficient means to recover it, what was sold shall remain with the purchaser until the year of jubilee; in the jubilee it shall be released, and the property shall be returned. (Lv 25:28)

(35) If any of your kin fall into poverty and become dependent on you, you shall support them; they shall live with you as though resident aliens.

(36) Do not take interest in advance or otherwise make a profit from them, but fear your God; let them live with you.

(37) You shall not lend them your money at interest taken in advance, or provide them food at a profit. (Lv 25:35-37)

(39) If any who are dependent on you become so impoverished that they sell themselves to you, you shall not make them serve as slaves.
(40) They shall remain with you as hired or bound laborers. They shall serve with you until the year of the jubilee.

(41) Then they and their children with them shall be free from your authority; they shall go back to their own family and return to their ancestral property.

(42) For they are my servants, whom I brought out of the land of Egypt; they shall not be sold as slaves are sold. (Lv 25:39-42)

Meyer (2005) interprets the rulings of Leviticus as pertaining to the returnees after the exile, which meant the restoration of the former elite who went into exile, and not the poor who stayed behind. For the latter, it could have meant the continuation of poverty. Therefore the poor are not specifically mentioned in Leviticus $25: 1-5$. As the biblical text originated and initially functioned in the circle of the elite, this could well have been its initial communication. In the reception of the text, and perhaps also as intended by the final redactor of the Pentateuch, a more inclusive meaning could well have been intended. Meyer (2005:279-286) concludes correctly that in the present-day context the text can only communicate positively if its exclusive features are put aside and if all people are included as the beneficiaries of the measures.

Scholars doubt that even in the ancient context the measures had the desired effect and that it is possible that it was never implemented..$^{23}$ In an age where the human life span was very short, one can ask what after all is the benefit of receiving your property back only after 50 years when most of your life has already passed? However, the jubilee was treasured as a positive ideal when the poor will ultimately receive justice and, as such, it was appropriated in Isaiah 61:2 for the poor in the post-exilic context. In Luke's Gospel, the coming of Jesus and his preaching to the poor and the lowly was clearly typified by it, as is clear from the fact that Luke quotes from Isaiah 61:1-3 in Luke 4:18 (see Scheffler 1991:101-105). Not the contingent measures, but the idea behind it was positively interpreted and Jesus coming is typified as a jubilee year.

One can conclude that definite measures were prescribed in ancient Israelite society, not merely to care for the poor, but to combat poverty. The view of the past in terms of the Exodus or liberation from Egypt (Ex 1-15), the interpretation of experienced poverty in the desert as a testing to keep the Israelites free from apostasy (Dt 8), the idea of family solidarity (Dt 15) and Yahweh's holiness and compassion (Lv 17-25) functioned as motivating factors that would ensure the implementation of the prescriptions. In the reality of Israel's subsequent history the measures of course had only some of the desired effect.

\section{Present-day challenges}

Our observations on poverty in the Pentateuch have surprisingly relevant dimensions and correspondences with our present-day situation, to such an extent that we (although maintaining the critical dialogue) are encouraged to move

23.On the basis of Leviticus $26: 43$, 2 Chronicles $36: 21$, Ezra 7:13; $46: 17$ and Luke $4: 18-19$, Maarsingh (1974:226-227) concludes that the keeping of the Sabbath year and jubilee was unsure, but nevertheless treasured as an ideal. In 1 Maccabees 6:48-54 it seems as if the Sabbath year was kept, but it led to poverty! 
forward reflecting on present-day challenges. Within the context of extreme poverty in (Africa and) the world the following issues seem to be relevant.

\section{Compassion motivated by own suffering}

The Pentateuch was not written by poor people but the religious elite of ancient Israel, who constituted only a small minority of the population. However, the god they worshipped was continually portrayed as one having compassion for the poor and down-trodden, expecting a similar compassion from those who worship him. This motif was, on numerous occasions, motivated by the Exodus experience which narrates Israel's liberation from slavery. This transcending of their own interest is unique to Israelite religion and forms not only the basis of the Mosaic Laws, but also the prophetic critique regarding poverty in the 9 th -7 th centuries, the prominent contemplation on poverty in the wisdom tradition, Israel's poetry, with a radical culmination in the teaching and ministry of Jesus of Nazareth.

\section{Working for change despite failures}

Even when laws are made or measures advocated in specific contexts (past or present) to eradicate or ameliorate poverty, and these attempts prove to be impractical, the good intention behind the measures should still serve, like the jubilee year, as a source of inspiration. With zeal the search should go on for measures that work. The egalitarian measures of Deuteronomy 15 and Leviticus 25 (in the ancient context) and communism as advocated by Marx (in the modern context) can be mentioned as examples of motivation to change society for the benefit of the poor, preventing religion from functioning as 'opium for the people', promising a pie in the sky whilst keeping unjust distinctions and suffering intact. ${ }^{24}$ This seems also to be the stance to be distinguished in the Pentateuch, after all Israel's failures in this regard.

\section{Acting as 'free agent' to the benefit of the poor}

Appropriation of perspectives on poverty in the Pentateuch is not best served by only exegeting and then applying specific texts on a linear basis, but by reading the Pentateuch repeatedly with an attitude of empathy for the poor in mind and by internalising the positive perspectives of the Pentateuch, even on a subconscious level. The present-day reader thereby becomes empowered to act as 'a free agent' (cf. Barr 1973) to the benefit of the poor in his or her own specific contexts.

\section{The dispelling of a dangerous contemporary myth}

Often when people are challenged (by the stance of the historical Jesus or otherwise) to contribute to poverty eradication, the reply is something like, 'Jesus also said: "The poor will always be amongst us"', not even knowing that they refer to Jesus' reply to a complaint because a woman

24.Moltmann (1964:74) remarks: 'Für den Theologen geht es nich darum, die Welt die Geschichte und das Menschen nur anders zu interpretieren, sondern sie in der Erwartung göttliche Veränderung zu verändern.' ['The theologian is not concerned merely to supply a different interpretation of the world, of history and of human nature, but to transform them in expectation of divine transformation.'] threw expensive oil (which could have benefited the poor) on Jesus' head or feet (cf. Mt 26:11; Mk 14:7; Lk 7:36-50 and Jn 12:7). ${ }^{25}$ Beside the fact that the rest of Jesus' remark, 'and you can be kind to them whenever you wish, but you do not always have $\mathrm{me}^{\prime}$, is conveniently left out, whereby the remark is interpreted flagrantly out of context, the despondent misquoting of Jesus can easily be proven from many other gospel texts to be a fallacy (see Scheffler 2011b).

Jesus was, of course, quoting Deutronomy 15:11. We have already noted that the remark in Deuteronomy functions in the text as a spur to alleviate poverty and not as a despondent pronouncement that should have a detrimental effect on efforts to eradicate poverty. Perhaps the greatest obstacle in the endeavour to eradicate poverty is the myth that it is impossible to put an end to it. There is an urgent need to dispel this myth.

Can extreme poverty be ended, or should we interpret Deuteronomy 15:11 as saying that it is impossible? If there will always be poor people, does that mean poverty on a vast scale or amongst some individuals in society? What kind of poverty is meant - extreme, moderate or relative poverty?

Apart from the fact of a virtual end to extreme poverty in Europe in the past two centuries, there is also a marked decrease in extreme poverty in Asia as a result of the economic boom. According to Sachs (2005b:34), extreme poverty can be wiped out in Africa by 2025 if enough money is mustered and spent correctly. If what he calls 'clinical economics' is applied, whereby existing knowledge on development is put into practice, astounding results can be obtained. The problem is the human will to do it (see below).

\section{Humankind as a global family}

In Deuteronomy 15, a clear distinction is made between the ach [brother] and nokri [foreigner]. Seventh century Judeans are called to care for the members of their own nation, whom they should love as brothers - and not for people of other countries. They may lend to and recover debts from these people with the expectation of lending to them and even ruling over them. Whether this should be interpreted as altruistic or egotistic behaviour is debatable. What should be kept in mind is that the precepts from Deuteronomy come from a context that is 27 centuries removed from ours, from a pre-industrial and non-globalised world where all countries were relatively poor (even Europe). In the globalised world of today, who would qualify as a 'brother' (and sister) definitely needs a rethink. From the text of Deuteronomy 15, not an exclusivist, but the positive (universal, inclusive) value of striving to live in a close-knit community where poverty is absent should be kept alive.

Globalisation is not a choice for individual people or nations, but an event that occurs automatically (cf. Du Toit \& Lubbe 2012). With the available resources (e.g. information technology and possibilities of transport) the world has

25.Jesus' reference is omitted in Luke's version ( $(2 \mathrm{k}$ 7:36-50), probably to avoid any misunderstanding and in line with his positive emphasis on the poor. 
become a smaller community (the proverbial 'global village'). Through globalisation, the world has the potential to develop into one big capitalistic community, with a smaller number of companies having a bigger share of the cake. The negative effect here is that poorer communities are left behind, being unable to compete.

Although globalisation therefore seems to be unavoidable with its positive and negative effects, human beings and their governments have a choice on how to react to it. And such a choice can be informed by a critical appropriation of Deuteronomy 15, especially verses 4 and 11. In such a vision of brotherhood and sisterhood, distinctions between the ach and nokri fall away not only as a result of globalisation, but because of a conscious decision. The modern-day counterpart of the Judean community of the 7 th century is to be interpreted not as any other exclusivist national community, but as the world community at large. No human being on the globe should be poor.

\section{The possibility of present-day debt release to poor nations}

There are two ways in which the text of Deuteronomy 15 examines the issue of poverty in the 7 th century Judean society, namely the release of debts and the lending of money. What we can deduce from the text is that the lending of money to debtors should be done with a view to helping them and not to exploiting them, to alleviating poverty and not to creating it. If the poverty had also been caused by other circumstances, the creditor should write off the debts because poverty was regarded as an evil ${ }^{26}$ that should not exist in a society founded on a sense of kinship and solidarity. It is interesting to note that the precepts do not involve mere hand-outs but the measures (debt release, lending, even-handed justice, pledging, not full harvesting, jubilee rights) that preserve the dignity of the receivers in a spirit of solidarity.

Today the writing off of debts of poor African countries is very much on the cards and the relevant biblical texts (Sabbath as well as jubilee year) have often been quoted to substantiate such actions (see Rogerson 2003:161). Seen from the perspective of the alleviation of poverty, the writing off of debts is meant to enable poor countries' governments to take part in alleviating poverty amongst their own people, whilst not being hampered by the burden of past debts. According to McAllister (2005:19), Africa still owes $\$ 293$ billion and pays $\$ 15$ billion a year in interest and fees. Some poor African countries therefore spend more on servicing debt than on health and education. Because aid to the poor should not be mere hand-outs that are open to corruption (thus continuing situations of poverty), it seems to be correct that Developed World governments demand fair government from debtor nations and insist that the process of alleviation of poverty

26.That poverty is seen as evil and 'uprooting' (cf. the double-pronged title of Wilson and Ramphele's book [1989]) in the Pentateuch is very significant in the light of views in later Judean and early Christian society (not in linewith the stance of the historical Jesus who pronounced the poor blessed and never idealised poverty), where the concept is spiritualised and even seen as a virtue. Although there is some room for sobriety to be regarded as a virtue, to my mind the view(s) of the Pentateuch text are more appropriate for the present-day situation. To idealis poverty is to perpetuate poverty and human misery. should be done in partnership. However, ways should still be explored to help the innocent poor people on the ground in countries with corrupt governments.

\section{Poverty eradication and ecology}

Today the correlation between poverty and ecology is increasingly realised. It still astounds that in the endeavour to secure the future through money, capitalist-driven societies have violated the earth to a great extent. The desire for wealth and luxury is so great that it is often not realised that the branch on which one sits on the tree is being cut off (cf. Fromm 1976:13-23). Here the direct application of the Pentateuch texts can almost be made. In the Covenant Code (Ex 23:10-11; for longer version see Lv 25:3-7), it is stipulated that the land should lie fallow (also applying to vineyards and olive orchards) every 7 th year and that then only the poor may eat that grows there. Because of Africa's poverty, small pieces of land are often exploited to such an extent that in the long run the land is not able to produce enough for the poor who are dependent on it. To be kind to the land as such should therefore be interpreted as to the benefit of the poor (as it was to the poor and animals[!] in the original law).

A conservational ecological approach to Africa's land in the present-day world has another advantage for the poor, as well as the world at large, constituting a win-win situation. Tourism is a phenomenon of the modern world that constitutes a 'natural means' for the distribution of wealth. Instead of mere hand-outs, it preserves the dignity of the poor nations by providing them the opportunity to outgrow their poverty through honest work. It also brings the people of the Developed World into direct contact with the poor, so that financial contributions to the poor do not function as 'indulgence' money. It is said that 10 tourists to South Africa provide one job opportunity.

Although tourism in the modern sense did not exist in ancient Israel in which the Covenant and Holiness Codes originally functioned, it is in line with the basic spirit that emanates from the text and the text behind the text (preservation of the land and solidarity).

\section{Prophetic critique and 'powerless' 'pro-the-poor' government}

The critique of the later prophets (e.g. Isaiah, Jeremiah, Amos and Micah) against corrupt leaders in the interest of the poor was based on the fact that measures prescribed in the Torah were not heeded. It is important to realise that this prophetic voice is already present in the Pentateuch itself. In Deuteronomy 17:14-20, limits are set to the powers of the king in view of past experiences. ${ }^{27}$ Deuteronomy 17:17 stipulates that the king should not accumulate great wealth for himself. Moreover, he should have a copy of the Mosaic Law, read and contemplate it continually, fear Yahweh, act according to its stipulations and not exalt himself above his brothers (Dt 17:18-20). It stands to reason that all the laws 27. For an elaborate discussion of the passage see Scheffler (2007). 
regarding poverty prevention are included. Deuteronomy 17 therefore challenges the reader to see to it that the king abide by these principles and should exert prophetic critique where necessary.

The relevance for the South African (and other) situation(s) is obvious. In 1998, Mandela (2011:65) remarked: 'We have learnt now that even those people with whom we fought the struggle against apartheid's corruption can themselves become corrupted'. For an example of such a prophetic critique (ironically not from church or theological origin) see Basson (2012).

\section{Slavery and low wages}

In the Pentateuch, relative kindness to slaves is usually discussed in the context of other poverty eradication measures (cf. Lv 25:39-42; Dt 15:1-18). By their very status, slaves were poor and the release of slaves in the 7th year (again only within the exclusive circle of Judean society) can be interpreted as a stance for the abolition of slavery altogether as it indeed envisioned in the Holiness Code (Lv 25:39-42). Explicit measures were in place so that slaves would not be poor at their release. They (male as well as female slaves!) should not be sent away empty-handed but should receive wealth (sheep, corn and wine) from their former masters. Provision was even made for slaves to stay on as servants if they themselves deemed they would be better off. The suggestion that slaves in some situations 'loved' their masters and his family also indicates that the text reflects an ideal of good labour relations. Within the oppressive situation of slavery and exploitation, a degree of 'humanity' was still deemed possible.

The emphasis on poverty in the slave laws compels us in our contemporary situation to reflect on the issue of slavery in our contemporary world, despite the fact that slavery was officially abolished in the early 18th century. In South Africa, slavery is not allowed, but are the free people better off? ${ }^{28}$ The question should be posed in terms of low wages that are earned on some South African farms and other institutions. Despite government legislation that prescribes a minimum wage of approximately R100 per day (putting people just into the category of relative poverty), in many instances they still earn less.

As about $25 \%$ of the people in the labour market in South Africa are jobless, the law of supply and demand still rules. The result is that about $50 \%$ of all Black South Africans (15 million) are exposed to the poverty that kills. And the figures amongst poor White South Africans are increasing.

A first measure would be to extend the present grant of about R1200 (a mere R40 per day) to all jobless people, thereby eradicating extreme poverty by the stroke of a pen. For this purpose, there is enough money in the treasury and

28.A remnant of the era of slavery still exists widely in the language still being used between 'patrons' and 'clients' in the South African labour market. Farmers are still widely addressed as 'boss' or 'master' instead of more usual forms of address (e.g. 'sir'). it astounds that a government that pretends to be "pro-thepoor' refrains from doing it (despite the recommendations by economists, cf. Botha 2012).

\section{Towards poverty eradication today}

The overall message that we can obtain from the Pentateuch is that poverty should be eradicated and that a wide variety of means, relevant to the situation, should be employed to accomplish it. This entails individual behaviour as well as behaviour by the state on a macro level. However, many people still doubt the possibility of poverty eradication. Sachs (2005a, 2005b), as an economist, has the contrary opinion and, according to Mills (2010), 'poverty is now optional'. What is important is the effort and possibilities on a macro level because success there could make a huge difference.

According to Sachs (2005a), the price of eradicating extreme poverty in Africa is relatively cheap. Developed World nations should budget $0.70 \%$ of their gross national income (GNI) for it, targets that are already met by Sweden, the Netherlands and Norway and promised by Germany. Unfortunately, the USA is only spending $0.16 \%$ of its GNI per year on African poverty relief (about $\$ 16$ billion, whereas they spend 30 times more on the military). One of the USA's reasons for not giving more aid to Africa is the existence of corruption in African governments and nondemocratic systems of government. However, the children who will die of hunger have no stake in government corruption levels, nor are they responsible for government systems.

Furthermore, Sachs (2005a:34) suggests that money should not merely be given to governments, but should be given for development interventions (known, proven, reliable and appropriate technologies), which should be carried out in partnership between donor countries and the governments of receiving communities. 'Indulgence money' without involvement should therefore be avoided. In what he calls clinical economics, Sachs (2005a:233-234) distinguishes five specific courses of action. Firstly, the boosting of agriculture with fertilisers, cover crops, irrigation and improved seeds which can triple food production with the current productivity levels of local farmers. This will quickly end chronic hunger. Secondly, improving basic health means that for every 5000 people a village clinic with one doctor and one nurse is needed. Thirdly, investing in education involves meals for children at school and added training in skills of farming, computer literacy, infrastructure maintenance and carpentry. Fourthly, electricity provides light and will enable learners to study at night. It makes computers accessible for schools, pumps for safe well water, power for milling grain, refrigeration, et cetera. Fifthly, if clean water and sanitation are provided, the health of the people is improved and working hours saved.

In Sach's (2005a) view, the cost of achieving developmental goals is relatively cheap (about $\$ 70$ per person per year). To get rid of extreme poverty in rural communities of a country such as Kenya would cost $\$ 1.5$ billion a year, 300 times less than America's military budget. According to him: 
Sooner rather than later, these investments would repay themselves not only in lives saved, children educated and communities preserved, but also in direct commercial returns to the villages and the chance for self-sustaining economic growth. (Sachs 2005b:34)

Sachs's proposed measures amount to giving a fish to the hungry, as well as teaching them to fish. In a recent publication (after the recession starting in 2008), he most significantly reflected on the failure to achieve these goals. Even more significantly he - as an economist - ascribed it to the absence of 'the glue of compassion that hold societies together' (Sachs 2011:5).

Is it perhaps possible that reading and reflecting on the 'pro-the-poor' stance(s) in the Pentateuch can provide that compassion?

\section{Conclusion}

The Pentateuch contains different, but definite, contingent and specific measures to combat poverty. These measures cannot be applied to today's contexts in the same form. The Sabbath and jubilee years could even be economically unproductive in today's world. However, it should be constantly remembered that the measures arose from a basic pro-the-poor stance based on Yahweh's compassion as expressed in the Exodus event. However, studying poverty in the Pentateuch reminds us that theologising and reflecting on the poor in an armchair fashion is not enough. Philosophising about poverty is an inherent contradiction. Proper action should be taken, suitably and in accordance with the demands of various contexts (whether they be African or Asian, or even unnoticed instances of extreme poverty in the Developed World). In view of new contexts, traditions of the past can be reinterpreted (as happened in the case of the Sabbath year). As such, the views expressed in the Pentateuch serve as a corrective on views often expressed when the concept of the poor is often spiritualised or theologised and where the recognised involvement of God with the fate of the poor is employed by the petitioner in terms of his or her own plight, but not for the alleviation of poverty as such (e.g. Ps 109 referred to above).

Also, the stance that can be derived from the Pentateuch is balanced in the sense that merely employing blind laws and measures, apart from the worldview, feelings and experience of living human beings, is not enough to guarantee the eradication of poverty. According to Deuteronomy 15, measures to alleviate poverty are inspired by and based on the concept of the society as family, where one's actions are motivated by a sense of kinship and a 'non-hardening of the heart'. Deuteronomy 15 presents us with an exclusively national (probably early post-exilic) Jewish interest. However, this exclusivity was opened up by Jesus of Nazareth and his movement and was continued in early Christianity. Of course, exclusivity has re-entered Christian thought over the centuries. The survival of Christianity, and indeed the justification of its existence in a globalised world today, depend on the continued appropriation of its initial stance (family love or solidarity that crosses ethnic boundaries).

\section{Acknowledgements Competing interests}

The author declares that he has no financial or personal relationships that may have inappropriately influenced him in writing this article.

\section{References}

Barr, J., 1973, The Bible in the modern world, SCM, London.

Basson, A., 2012, Zuma exposed, Jonathan Ball, Johannesburg.

Berges, U., 2000, 'Armoede en haar bestrijding in de wetten van het Oude Testament', Tijdschrift Voor Theologie 40(3), 227-250.

Blomberg, C., 1999, Neither poverty nor riches: A biblical theology of material possessions, Apollos, Leicester.

Botha, R., 2012, Televison interview with Freek Robinson, Robinson Regstreeks, Kyknet Channel.

Clines, D., 1976, The theme of the Pentateuch, Sheffield Academic Press, Sheffield.

Clines, D., 1995, Interested parties: The ideology of writers and readers of the Hebrew Bible, Sheffield Academic Press, Sheffield.

Clines, D. (eds.), 2009, The concise dictionary of classical Hebrew, Sheffield Phoenix Press, Sheffield.

De Wette, W.L.M., 1869, Lehrbuch der historisch-kritischen Einleitung in die kanonischen und apokryphischen Bücher des Alten Testaments, De Gruyter, Berlin.

Deist, F., 1988, 'The Hexateuch', in H.L. Bosman \& J.A. Loader (eds.), Old Testament storytellers, Tafelberg Publishers, Cape Town. PMCid:PMC1542022

Du Toit, C. \& Lubbe, G.J.A., 2002, After September 11: Globalisation, war and peace, Unisa Press, Pretoria.

Eissfeldt, O., 1964, Einleitung in da Alte Testament, 3. Aufl., Mohr Siebeck, Tübingen.

Farisani, E., 2012, 'The Naboth's vineyard story (1 Ki 21) and poverty eradication', in E. Scheffler \& W. van Heerden (eds.), The Bible and the eradication of poverty: Study Guide 1 for OTS2604, pp. 60-73, Unisa, Pretoria.

Fletcher, J., 1966, Situation ethics, SCM, London.

Fromm, E., 1976, Haben oder Sein: Die seelische Grundlagen einer neuen Gesellschaft, Deutscher Taschenbuch Verlag, Munich.

Groenewald, A., 2003, Psalm 69: Its structure, redaction and composition, Lit Verlag, Münster.

Le Roux, J.H., 2005, 'Pro Pent: A project for the study of the Pentateuch in South Africa', in E. Otto \& J.H. le Roux (eds.), A critical study of the Pentateuch: An encounter between Europe and Africa, pp. 1-21, Lit Verlag, Münster.

Lisowsky, G., 1958, Konkordanz zum Hebräischen Alten Testament, 2. Aufl., Württembergische Bibelanstalt, Stuttgart.

Loader, J., n.d., 'Chokma-Joseph-Hybris', Ou Testamentiese Werkgemeenskap van Suid-Afrika 17/18, 2-31.

Lötter, H., 2008, When I needed a neighbour were you there? Christians and the challenge of poverty, Lux Verbi, Wellington.

Maarsingh, B., 1974, Leviticus, Callenbach, Nijkerk. (POT).

Mandela, N., 2011, Nelson Mandela by himself: The authorised book of quotations, Pan Macmillan, Johannesburg.

Martin-Achard, R., 1976, 'Anah II elend sein', in E. Jenni \& C. Westermann (eds.), Theologisches Handwörterbuch zum Alten Testament, vol. II, pp. 342-350, Kaiser Verlag, Munich.

McAllister, J.F.O., 2005, 'Promises to keep', Time 165(11), 37.

Meyer, E.E., 2005, The Jubilee in Leviticus 25: A theological ethical interpretation from a South African perspective, Lit Verlag, Münster.

Mills, G., 2010, Why Africa is poor and what Africans can do about it, Penguin, Johannesburg.

Moltmann, J., 1964, Theologie der Hoffnung, Kaiser Verlag, Munich.

Oosthuizen, M., 1997, 'Deuteronomy 15:1-18 from a socio-rhetorical perspective', Zeitschrift für Altorientalische und Biblische Rechtsgeschichte 3, 64-91.

Otto, E., 1994, Theologische Ethik des Alten Testaments, Kohlhammer, Stuttgart.

Otto, E., 2000, Das Deuteronomium im Pentateuch und Hexateuch: Studien zur Literaturgeschichte von Pentateuch und Hexateuch im Lichte des Deuteronomiumrahmens, Mohr \& Siebeck, Tübingen.

Rogerson, J., 2003, 'Deutronomy', in J. Dunn \& J. Rogerson (eds.), Eerdmans commentary on the Bible, pp. 153-173, Eerdmans, Cambridge.

Sachs, J., 2005a, The end of poverty: How we can make it happen in our life time, Penguin, London.

Sachs, J., 2005b, 'The end of poverty', Time 165(11), 26-36.

Sachs, J., 2011, The price of civilisation: Economics and ethics after the fall, The Bodley Head, London.

Scheepers, C., 2012, 'Survival strategies in ancient Israel: An archaeological perspective', in E. Scheffler \& W. van Heerden (eds.), The Bible and the eradication of poverty: Study Guide 1 for OTS2604, pp. 23-41, Unisa, Pretoria. 
Schröter, J., 2007, Von Jesus zum Neuen Testament, Mohr Siebeck, Tübingen.

Scheffler, E., 1991, 'Good news for the poor: How does the New Testament use the Old?', in H.L. Bosman, I.G.P. Gous \& I.J.J. Spangenberg (eds.), Plutocrats and paupers: Wealth and poverty in the Old Testament, pp. 96-107, Van Schaik, Pretoria.

Scheffler, E., 1993, Suffering in Luke's gospel, Theologischer Verlag, Zürich.

Scheffler, E., 2000, Fascinating discoveries from the biblical world, Biblia, Pretoria. PMCid:PMC101787

Scheffler, E., 2005, 'Deuteronomium 15:1-18 and poverty in (South) Africa', in E. Otto \& J.H. le Roux (eds.), A critical study of the Pentateuch, pp. 97-115, Lit Verlag, Münster.

Scheffler, E., 2007, 'Criticising political power: The challenge of Deuteronomy 17:14-20', Old Testament Essays 20(3), 772-785.

Scheffler, E., 2008, 'Deuteronomium 15:1-18 en die uitroei van armoede in (Suid-) Afrika', Verbum et Ecclesia 29(1), 194-221. http://dx.doi.org/10.4102/ve.v29i1.13

Scheffler, E., 2009, 'Leviticus 25:1-7, ecology and (Southern-) Africa', Theologia Viatorum $33(2), 468-489$.
Scheffler, E., 2011a, 'Pleading poverty (Or: Identifying with the poor for selfish reasons): On the ideology of Psalm 109', Old Testament Essays 24(1), 192-207.

Scheffler, E., 2011b, 'Luke's view of poverty in ancient (Roman) economic context: A Challenge for today', Scriptura 106, 115-135.

Scheffler, E., 2012, 'Poverty in the book of Proverbs: Looking from above?', Scriptura $111,480-496$.

Schmithals, W., 1980, Das Evangelium nach Lukas, Theologischer Verlag, Zürich. Spangenberg, I., 2012, 'Poverty eradication in Israel's wisdom literature', in E. Scheffler
\& W. van Heerden (eds.), The Bible and the eradication of poverty: Study Guide 1 for OTS2604, pp. 105-124, Unisa, Pretoria.

Von Rad, G., 1974, Gottes Wirken in Israel: Vorträge zum Alten Testament, Neukirchener Verlag, Neukirchen.

Wilson, F. \& Ramphele, M., 1989, Uprooting poverty: The South African challenge, David Philip, Cape Town.

Zenger, E., 1998, Einleitung in das Alte Testament, 3. Aufl, Kohlhammer, Stuttgart. PMid:9773874 